\title{
Use of Pyracantha coccinea Roem. as a possible biomonitor for the selected heavy metals
}

\author{
${ }^{1}$ N. Akguc; ${ }^{1 *}$ I. I. Ozyigit; ${ }^{2}$ U. Yasar; ${ }^{3}$ Z. Leblebici; ${ }^{1}$ C. Yarci \\ ${ }^{1}$ Marmara University, Faculty of Science and Arts, Department of Biology, 34722, Goztepe, Istanbul, Turkey \\ ${ }^{2}$ Bartin University, Faculty of Engineering, Department of Environmental Engineering, 74100, Bartın, Turkey \\ ${ }^{3}$ Erciyes University, Faculty of Science and Arts, Department of Biology, 38039, Kayseri, Turkey \\ Received 3 February 2010; $\quad$ revised 29 March 2010; $\quad$ accepted 2 May 2010; availaEФுonline 1 June 2010
}

\begin{abstract}
In this study, copper, iron, manganese and nickel levels of branches and leaves of Pyracantha coccinea Roem. (firethorn) were measured for determining the heavy metal pollution in Mugla Province. Plant samples were collected from 34 different localities in four different areas of Mugla Province, during 2006 vegetation period. Unwashed and washed leaf samples and unwashed branch samples were subjected to analysis and copper, iron, manganese and nickel concentrations of samples were measured by inductively coupled plasma optical emission spectrometry. The obtained data were analyzed with "statistical package for the social sciences" statistics program. As a result of measurements, the highest average and lowest values and their collected stations were as follows; the highest average $(5.89 \pm 0.04 \mu \mathrm{g} / \mathrm{g} \mathrm{dw})$ and the lowest $(5.20 \pm 0.03 \mu \mathrm{g} / \mathrm{g} \mathrm{dw})$ values of copper were measured near highways. The average highest iron value $(9.53 \pm 1.68 \mu \mathrm{g} / \mathrm{g} \mathrm{dw})$ was in industrial area while the lowest was near highways $(1.73 \pm 0.54 \mu \mathrm{g} / \mathrm{g} \mathrm{dw})$. The highest value of magnesium accumulation $(1.00 \pm 0.16 \mu \mathrm{g} / \mathrm{gdw})$ was measured near highways. The lowest value was determined in urban area $(0.40 \pm 0.14 \mu \mathrm{g} / \mathrm{g} \mathrm{dw})$. The average highest level of nickel was in industrial area while the lowest was determined in urban area. The values were $14.34 \pm 1.59 \mu \mathrm{g} / \mathrm{g}$ and $4.05 \pm 0.51 \mu \mathrm{g} / \mathrm{g} \mathrm{dw}$. As a result, it was proven that $P$. coccinea could be used as a biomonitor species for some of these heavy metals especially for copper and nickel.
\end{abstract}

Keywords: Biomonitor; Firethorn; Heavy metal; Mugla

\section{INTRODUCTION}

A great quantity of heavy metals and other chemicals, especially produced by industries, agriculture, mining, combustion of fossil fuels and traffic are often released to the atmosphere, soil and water. They aggressively manifested on terrestrial and aquatic flora and fauna (Celik et al., 2005; Okafor and Opuene 2007; Mahvi, 2008; Yasar et al., 2010). Heavy metals easily accumulate in large quantities in plant tissues with no visible phytotoxicity, but exceed human and animal tolerance (Kovalchuk et al., 2001; Prasad and Freitas, 2003). For years, both tolerable and lethal dose of toxic compounds for different plants have been established and in some cases, the modification of chemical composition of the plants under the action of pollutants has been observed (Kabata-Pendias and Pendias, 2001; Nameni et al., 2008).

The use of biological materials to measure environmental effects of atmospheric deposition was first reported by Nylander (1886). Since then, his report

*Corresponding Author Email: ilkozyigit@marmara.edu.tr Tel.: +90216346 4553, Fax: + 902163478783 on the epiphytic lichens of Paris and its surroundings has been performed in many areas (Wolterbeek, 2002). In the past few decades, an increasing use of higher plant leaves as biomonitors for heavy metal pollution has been seen in the environment and especially in urban areas (Aksoy et al., 1999; Yilmaz et al., 2006; Yasar et al., 2010). Today, not only the vegetal sources (lichens, mosses, tree barks, tree rings, pine needles, grasses and leaves) but also many other living organisms (mollusks, fishes, birds and cyanobacteria) are being used as biomonitors to detect deposition, accumulation and distribution of metal pollution (Sakurai et al., 2000; Figueiredo et al., 2007; Akguc et al., 2008; Aksoy, 2008; Yasar and Ozyigit, 2009). Although there are many types of biomonitors, lower plants, especially mosses, algae and lichens are the most frequently used organisms for monitoring metal pollution in urban environments since they have a higher metal accumulation capacity (Aksoy and Ozturk, 1997; Augusto et al., 2007; Akguc et al., 2008; Yasar 
and Ozyigit, 2009). Therefore, selection of a biomonitor plant is an important criterion to be successful in a scientific study on heavy metal pollution in any environment (Akguc et al., 2008; Malakootian et al., 2009). However, a good biomonitor will indicate the presence of the pollutant and provide additional information about the quantity and intensity of the exposure (Wolterbeek, 2002). In addition, it should differentiate between both air- and soil-borne heavy metal contaminations, easy to sample and has no identification problems. It is expected to represent large numbers in all over the study area and to have a wide geographical range (Wittig, 1993). At present, no plant species that respond to a wide range of heavy metals as biomonitors are known (Mertens et al., 2005). Although white poplars are good biomonitors for As, Cd and $\mathrm{Zn}$ pollution in the soil, the same monitoring strategy would fail to reveal soil pollution, for $\mathrm{Pb}$ and $\mathrm{Cu}$ (Mertens et al., 2004). As a result, some plants can be more advantageous as biomonitors than other plants. For instance, perennial plants have a potential advantage over annual or shortliving perennials, which could enable monitoring of shortterm or yearly changes in pollution (Aksoy et al., 1999). In that case, the importance of the selection of a good biomonitor plant is coming into question once more.

In this study, Pyracantha coccinea Roem. (firethorn) was used as a possible biomonitor plant in Mugla Province (during vegetation period, in 2006 ). In this manner, the pollution levels of $\mathrm{Cu}, \mathrm{Fe}, \mathrm{Mn}$ and Ni metals have been observed particularly in urban areas such as along roadsides, because of the following characteristics: It grows easily in both urban and rural areas of various geographical ranges. Its ecological distribution can be found throughout Europe. It can be easily sampled, identified and cultivated and it is inexpensive to sample (Wittig, 1993; Akguc et al., 2008).

\section{MATERIALS AND METHODS}

\section{Study area}

Mugla City is located in the southwestern part of Turkey ( $37^{\circ} 12^{\prime}$ N, $28^{\circ} 21^{\prime}$ E) near the Aegean Sea. The coastline of the Mugla City is the longest among the Provinces of Turkey with $1.100 \mathrm{~km}$ (683 miles). The city is divided into 12 administrative districts (Fig. 1) (Mugla Municipality, 2010). Mugla is a rapidly growing city and its present population is estimated to be around 766.156 in whole city and 94.207 in city center (Tuikapp, 2010).

The economy of the city relies mainly on tourism (on the coast), agriculture (honey, pine-forest honey in particular and citrus fruits), forestry and marble quarries. The province is the second center of marble industry in Turkey after Afyon in terms of quantity, variety and quality. Other mines including coal in Yatagan and chrome in Fethiye are very important for Turkey's economy. The other industries in the province include SEKA Paper Mill in Dalaman and Yatagan Power Stations (Acar, 1998; Akguc et al., 2008).

\section{Botanical characteristics of Pyracantha coccinea} Roem.

Shrub up to $3 \mathrm{~m}$ high; young twigs grey-pubescent; spines leafless. Leaves lanceolate, elliptic or obovate elliptic, 2-4 (-5) × 1-1.5 (-2) cm, crenate-serrate, pubescent beneath, especially when young, or entirely glabrous;

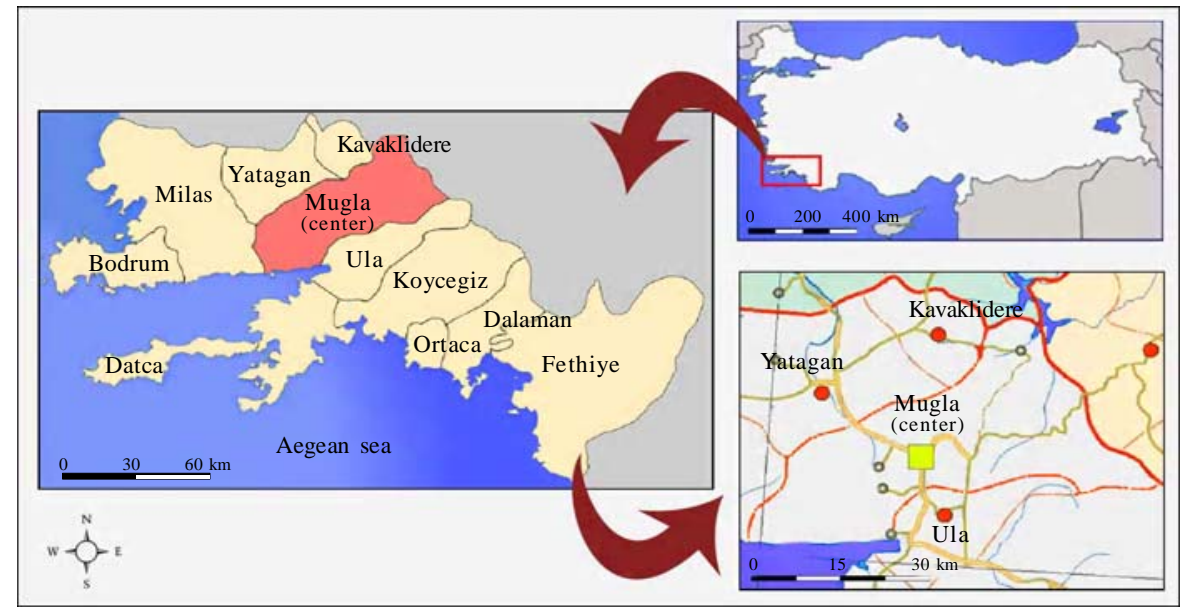

Fig. 1: Administrative districts of Mugla City in Turkey 
petioles 5-10 mm. Corymbus many-flowered. Flowers up to $8 \mathrm{~mm}$ diameter; pedicels $5 \mathrm{~mm}$. Fruit globose, $5-7 \mathrm{~mm}$ diameter, red or occasionally yellow orange. Flowers between April-June. Limestone slopes, sand dunes, in open woodland and scrub, 30-1800 m (Davis, 1972).

$P$. coccinea is distributed especially North, Central and South Anatolia in Turkey and South Europe, Crimea, Caucasia, Northwest Iran in the world; Wild in Turkey, especially near the Black Sea Coast. It has a very wide range of horticultural use, for its ornamental berries (Pyracantha). Several cultivars and at least three wild varieties have been described (incl. P. coccinea Roem. var. kuntayi Kasapligil in Bauhinia 1, 2:124, 1958). Most of these refer to minor variants, differing in the color of the fruits or in leaf pubescence, not considered further here (Davis, 1972). In cultivation, it does not prefer a particular type of soil and requires little or no supplemental fertilization. Full sun preferred but will grow in partial to fairly heavy shade. It tolerates atmospheric pollution and reasonable exposure. This species, especially the cultivar "Lelandii”, is notably resistant to honey fungus (Huxley, 1992). It is intolerant to root disturbance except when young, a good bee plant and birds are particularly attracted to the fruit of this plant (Bean, 1981; Huxley, 1992).

\section{Sample collection and preparation}

The plant samples were collected from different sites of Mugla Province in September 2006. Totally, 34 plant samples were cut and then they were labeled and kept in standard paper envelopes. The localities were categorized as follows: urban (twelve stations), industrial (eight stations), highway (eight stations) and control (six rural stations). The samples were especially taken from the sides, which are faced to the asphalts. Leaf samples were divided into two sub-samples; some of them were thoroughly washed with running deionized distilled water to remove dust particles in a standardized procedure, and rest of the leaves and the branch samples were untreated. All plant samples were oven-dried at $80{ }^{\circ} \mathrm{C}$ for $24 \mathrm{~h}$, milled in micro-hammer cutter and fed through a 1.5-mm sieve. Plant samples were then stored in clean self-sealing plastic bags in silica gel.

Dried and milled plant samples were measured as $200 \mathrm{~g}$ and put into Erlenmeyers and then six mL mixture of $65 \%$ nitric acid $\left(\mathrm{HNO}_{3}\right)$ and $70 \%$ perchloric acid $\left(\mathrm{HClO}_{4}\right)$ in 1:4 ratios was added in it. Later, they were incubated in hot water in $52^{\circ} \mathrm{C}$ for at least $2 \mathrm{~h}$ (Kacar and Inal, 2008). After $2 \mathrm{~h}$, the Erlenmeyers including dissolved samples in the acid mixture were put on hot-plates and the organic materials and acids were evaporated from the solutions. The rest of the solutions were completed to 25 $\mathrm{mL}$ by deionized distilled water and the new solutions were stored in glass bottles. Concentrations of $\mathrm{Cu}, \mathrm{Fe}$, $\mathrm{Mn}$ and $\mathrm{Ni}$ in the leaf and branch samples were then measured by inductively coupled plasma atomic emission spectroscopy (ICP-OES). The standard error values of the means were calculated for comparison of site categories. The wavelengths used for determination were $324.754 \mathrm{~nm}$ for $\mathrm{Cu}, 259.940 \mathrm{~nm}$ for Fe, $257.610 \mathrm{~nm}$ for $\mathrm{Mn}$ and $221.647 \mathrm{~nm}$ for $\mathrm{Ni}$. The standard error values of the means were calculated to compare the site categories. A paired $t$-test was performed to determine the significance of washing of the leaves, comparing heavy metal contents of washed and unwashed plant samples for each type of site and F-test (ANOVA) was performed to compare different localities.

\section{RESULTS AND DISCUSSION Copper}

The mean copper concentrations in leaves (washed and unwashed) and branches (unwashed) of $P$. coccinea are shown in Fig. 2a. As a result of measurements, the average highest value of $\mathrm{Cu}$ accumulation (5.89 \pm 0.04 $\mu \mathrm{g} / \mathrm{g} \mathrm{dw}$ ) was in the branch samples collected near highways, whilst the lowest was measured in the washed leaves $(5.20 \pm 0.03 \mu \mathrm{g} / \mathrm{g} \mathrm{dw})$ collected near highways as well. It was observed that the highest values were in branch samples, the second highest values were in leaf samples and the lowest values were in washed branch samples in all stations. However, the values of $\mathrm{Cu}$ concentrations in all samples and stations were very close to each other and it was seen that washing the leaves reduced $\mathrm{Cu}$ concentrations in small amounts; nevertheless, the reduction was significant (Table 1 ). In that case, it can be stated that the source of $\mathrm{Cu}$ accumulation in leaves is not mostly originated from airborne factors in Mugla Province like a similar study, realized in Spain by Madejon et al. (2006) with Olea europaea featured. In nature, copper occurs in rocks, water, air and it is an essential element for plant growth and development (Aksoy et al., 2005). It is also an important component for many enzymes, which catalyzes oxidation and reduction reactions. The main sources of $\mathrm{Cu}$ are home tools production, metal manipulating, timber industry and ashes (Aksoy et al., 2005). It is accepted that the normal limits of $\mathrm{Cu}$ concentrations in plants are in the range of 4-15 
$\mu \mathrm{g} / \mathrm{gdw}$ (Allaway, 1968; Bowen, 1979) and between 20$100 \mu \mathrm{g} / \mathrm{g} \mathrm{dw}$ are accepted as toxic values (Kabata-Pendias and Pendias, 2001). According to these values, the $\mathrm{Cu}$ concentrations in this study were within normal limits in Mugla Province. In a similar research, Aksoy and Ozturk (1997) used Nerium oleander as a biomonitor in Antalya and found minimum and maximum limits as 3.2-6.18 $\mu \mathrm{g} / \mathrm{g}$ $\mathrm{dw}$ in unwashed and 3-4.45 $\mu \mathrm{g} / \mathrm{g}$ dw in washed leaves. In some other works realized in Turkey, $\mathrm{Cu}$ amounts were higher than in Kayseri with Robinia pseudoacacia (Aksoy et al. 2000) and in Sivas with Pinus sylvestris and Robinia pseudoacacia (Elik and Akcay, 2000). The $\mathrm{Cu}$ measurements in Antalya (Nerium oleander) which is a well-known touristic city like Mugla, have a broad agreement with the results obtained in this study. Kayseri and Sivas are industrialized cities in Turkey and they are affected by strong heavy metal pollutant factors. For instance, Kayseri has a very big metal processing factory called Çinkur (Manganese-Lead Metal Industry). The factory produces $\mathrm{Cd}, \mathrm{Pb}$ and $\mathrm{Zn}$ based metallic products, which causes pollution due to lack of filter systems in its chimneys (Aksoy and Sahin, 1999). The highest values were obtained from the samples, which were collected near that factory. Sivas also has very big cement factories and other small industries. These factors could be the cause of the higher $\mathrm{Cu}$ concentrations in these cities. In different parts of Mugla City, Tuna et al. (2005) studied Pinus sp. and Olea europaea and their lower measurements (Pinus sp. $4.4 \mu \mathrm{g} / \mathrm{g} \mathrm{dw}$ and Olea europaea $6.4 \mu \mathrm{g} / \mathrm{g} \mathrm{dw}$ ) could be an evidence that there is no $\mathrm{Cu}$ pollution in Mugla City.

\section{Iron}

The average iron concentrations in both types of (unwashed and washed) leaves and branches (unwashed) are shown in Fig. 2b. In this study, the findings of Fe values are as follows; the maximum amount was in the unwashed leaf samples in industrial area $(9.53 \pm 1.68 \mu \mathrm{g} / \mathrm{g} \mathrm{dw})$ and the minimum Fe amount was in

Table 1: Total percentage of $\mathrm{Cu}, \mathrm{Fe}, \mathrm{Mn}$ and Ni removal from the leaf samples of Pyracantha coccinea Roem. through washing procedure in four different stations

\begin{tabular}{lcccc}
\hline $\begin{array}{l}\text { Station } \\
\text { type }\end{array}$ & $\begin{array}{c}\mathrm{Cu}(\%) \\
\text { removal }\end{array}$ & $\begin{array}{c}\text { Fe (\%) } \\
\text { removal }\end{array}$ & $\begin{array}{c}\text { Mn (\%) } \\
\text { removal }\end{array}$ & $\begin{array}{c}\text { Ni (\%) } \\
\text { removal }\end{array}$ \\
\hline Industrial & 8.78 & 40.57 & 19.23 & 59.53 \\
Urban & 5.27 & 47.42 & 33.08 & 16.55 \\
Highway & 3.57 & 18.01 & 52.85 & 26.32 \\
Control & 2.97 & 30.80 & 20.72 & 50.74 \\
F-test & $* * *$ & & & $* *$ \\
\hline
\end{tabular}

Significance of comparison means by ANOVA ( $F$-test) are indicated (**p $<0.01, * * * p<0.001$ significant) the branch samples near highways $(1.73 \pm 0.54)$. For all stations, the highest values were in unwashed leaf, the second highest values were in washed leaf and the lowest were in branch samples. Fe is mostly used in steel industry as a raw material, in paint industry with its oxidized form as pigment, as a compound in carbon and some other metals, in constructions and buildings (Taylor et al. 1988). Literature indicates that, the normal limits of Fe are in the range of 2-250 $\mu \mathrm{g} / \mathrm{g}$ for plants (Kabata-Pendias and Pendias, 2001). Levy et al. (1999) mentioned that Fe concentrations over $500 \mu \mathrm{g} / \mathrm{g}$ are toxic. As it is seen above, values of the current study are accepted as normal. It was also observed that, washing the leaves reduced the Fe concentrations dramatically (Table 1).

In the present study, measured Fe levels were very low. In other studies realized both in Turkey and other countries, the results were within normal limits or higher, related to environmental conditions and/or high Fe accumulation capacity of the plants used as biomonitors (Uhlig and Junttila, 2001; Madejon et al., 2006; Yasar et al., 2010). Celik et al. (2005) found Fe concentrations between 100.2-3087 $\mu \mathrm{g} / \mathrm{g}$ dw in Denizli using unwashed leaves of Robinia pseudoacacia. In another study, Pinus sylvestris (3800 $\mu \mathrm{g} / \mathrm{g} \mathrm{dw}$ ) and Robinia pseudoacacia $(6300 \mu \mathrm{g} / \mathrm{g} \mathrm{dw}$ ) were used in Sivas and the results were very high (Elik and Akcay, 2000). These higher Fe concentrations may be a result of long-time industrial activities in Denizli and Sivas. Czarnowska and Milewska (2000) measured leaf Fe amounts between $121-1056 \mu \mathrm{g} / \mathrm{g} \mathrm{dw}$ using Taraxacum officinale in Warsaw Polonia related with the distance to the motorways. In Mugla, the Fe values of unwashed leaves were $214.5 \mu \mathrm{g} / \mathrm{g} \mathrm{dw}$ in Pinus sp. and $241.6 \mu \mathrm{g} / \mathrm{g} \mathrm{dw}$ in Olea europaea can be taken as an evidence that $P$. coccinea could not be a good biomonitor for Fe metal.

\section{Manganese}

Manganese amounts in washed and unwashed leaves and unwashed branches of $P$. coccinea in four different types of localities are shown in Fig. 2c. The results were as follows: the highest $\mathrm{Mn}(1.00 \pm 0.16$ $\mu \mathrm{g} / \mathrm{gdw}$ ) was measured in unwashed leaf samples collected near highways, whilst the lowest was measured in washed leaf samples $(0.40 \pm 0.14 \mu \mathrm{g} / \mathrm{gdw})$ collected in urban area. The second highest values were found in unwashed leaves and the lowest values were in branch samples excluding highway stations (Fig. 2c). In the literature, the normal limits of Mn concentrations in 
plants are in the range of $15-100 \mu \mathrm{g} / \mathrm{g} \mathrm{dw}$ and 300-500 $\mu \mathrm{g} / \mathrm{g} d \mathrm{dw}$ are toxic (Kabata-Pendias and Pendias, 2001). According to these values, in this study, the Mn concentrations are within normal limits and washing leaves reduced Mn levels (Table 1). In a study, Pinus sylvestris and Robinia pseudoacacia were used and the results were $50 \mu \mathrm{g} / \mathrm{gdw}$ and $93 \mu \mathrm{g} / \mathrm{g} \mathrm{dw}$, respectively(Elik and Akcay 2000). In many other studies realized in other countries, Mn values were variable. In Empetrum hermaphroditum and Vaccinium myrtillus $\mathrm{Mn}$ accumulation in unwashed leaves were between 533-3181 $\mu \mathrm{g} / \mathrm{gdw}$ and 44-659 $\mu \mathrm{g} / \mathrm{g} \mathrm{dw}$, respectively in Sor-Varanger, Norway (Uhlig and Junttila, 2001) and with Quercus ilex (318-2000 $\mu \mathrm{gg}$ dw unwashed leaves) and Olea europaea (46.2-418 $\mu \mathrm{g} / \mathrm{g}$ dw unwashed and $148 \mu \mathrm{g} / \mathrm{g} \mathrm{dw}$ washed leaves) in Spain (Madejon et al., 2006). These results are high and mostly over toxic values and this situation could be a result of higher $\mathrm{Mn}$ accumulation capacity of used plants and/or the environmental Mn pollution. The sources of Mn are mainly fossil oil's particles and smog, chemical manures, drain wastes in cities. In addition, iron and steel, battery, glass, ceramics, paint, lacquer and ink industries are the other important sources of $\mathrm{Mn}$, which dispersed in the atmosphere (Bowen, 1979). Tuna et al. (2005) in Mugla City, studied with Pinus sp. and Olea europaea and their results were 52.2 and $42 \mu \mathrm{g} / \mathrm{g} \mathrm{dw}$ in unwashed leaves. When the results are compared with results of Tuna et al. (2005) in Mugla, it can be suggested that $P$. coccinea could not be a good biomonitor for Mn like Fe.

\section{Nickel}

Nickel concentrations of three different samples (unwashed-washed leaves and branches) of $P$. coccinea are shown in Fig. 2d. As a result of measurements, the average highest levels of $\mathrm{Ni}$ were in industrial area (unwashed leaves) while the lowest was determined in urban area (branches). The values were $14.34 \pm 1.59$ $\mu \mathrm{g} / \mathrm{g}$ and $4.05 \pm 0.51 \mu \mathrm{g} / \mathrm{g} \mathrm{dw}$. Moreover, it was observed that the $\mathrm{Ni}$ concentrations reached the highest values in unwashed leaf samples in all stations. The second highest values were in washed leaf samples and the lowest values were measured in branch samples in all four different stations as well. The accepted Ni values in plant tissues are in the range of $0.5-5 \mu \mathrm{g} / \mathrm{g} \mathrm{dw}$ (KabataPendias and Pendias, 2001). According to the results of this study, current values are higher than normal limits. In the current study, washing leaves reduced the $\mathrm{Ni}$ values significantly (Fig. 2d). It can be said that divided particles of $\mathrm{Ni}$ and Ni-compounds are mainly carried by air. In nature, $\mathrm{Ni}$ is an abundant element and is naturally found in soil, water and food and is emitted from volcanoes. It occurs in the environment mainly in combination with arsenic, antimony and sulfur. Metallic nickel is found alloyed with iron in many meteors and the earth core is believed to contain substantial quantities. Commercially important nickel ores are garnierite, pyrrhotite and millerite. The sources of $\mathrm{Ni}$ are mainly vehicles running on petroleum and diesel fuel. They can easily contribute to nickel emissions to the atmosphere. Furthermore, consumer products that contain nickel and compounds are coins, jewellery, nickel-cadmium batteries, some paints and ceramics, magnetic tapes, computer components, goods containing stainless steel (sinks, cooking utensils, cutlery) (Nriagu, 1979; Kacar et al., 2002). Some scientists in Turkey carried out similar studies with some other plant taxa and different results were obtained. Elik and Akcay (2000) carried out a study in Sivas by using Pinus sylvestris and Robinia pseudoacacia's unwashed leaves and they found out the Ni values were $50 \mu \mathrm{g} / \mathrm{g} \mathrm{dw}$ and $93 \mu \mathrm{g} / \mathrm{g} \mathrm{dw}$ respectively. In different localities of Istanbul, $\mathrm{Ni}$ amounts were found between $2.19 \mu \mathrm{g} / \mathrm{g} \mathrm{dw}$ and 4.47 $\mu \mathrm{g} / \mathrm{g}$ dw by using Cercis siliquastrum subsp. siliquastrum L. (Yasar et al., 2010). In Mugla, Tuna et al. (2005) measured Ni in Pinus sp. (3.2 $\mu \mathrm{g} / \mathrm{g} \mathrm{dw}$ ) in Olea europaea $(3.9 \mu \mathrm{g} / \mathrm{g} \mathrm{dw})$. Higher results in Mugla may be due to locality differences in the same city or rapid $\mathrm{Ni}$ increase in the city during two years (from 2005 to 2007) or $P$. coccinea could be a better biomonitor than Pinus sp. and Olea europaea. There are some similar studies carried out in other countries by using different plant taxa as possible biomonitors. Uhlig and Junttila (2001) measured $\mathrm{Ni}$ accumulation in unwashed leaves of Empetrum hermaphroditum (2-14 $\mu \mathrm{g} / \mathrm{g} \mathrm{dw})$ and Vaccinium myrtillus (4-21 $\mu \mathrm{g} / \mathrm{g} \mathrm{dw}$ ) in Norway. Madejon et al. (2006) used Populus alba in New Zealand (1.33 $\mu \mathrm{g} / \mathrm{gdw}$ unwashed leaves) and Calzoni et al. (2007) measured $\mathrm{Ni}$ values between $8-14 \mu \mathrm{g} / \mathrm{g} \mathrm{dw}$ in unwashed leaves of Rosa rugosa in Italy. As seen in the results of these studies, only the Ni values of Populus alba in New Zealand are between the normal limits. Other values showed broad agreement with the current study and higher than normal limits. It can be said that like in our country, Ni values have been increasing in many countries. In addition, all the values were belonged to unwashed leaf samples and in the current study, washing leaves reduced the Ni values significantly (Table 1 ). In this study, it was observed that the concentrations of those four elements (Cu, Fe $\mathrm{Mn}$ and $\mathrm{Ni}$ ) increased with 
N. Akguc et al.
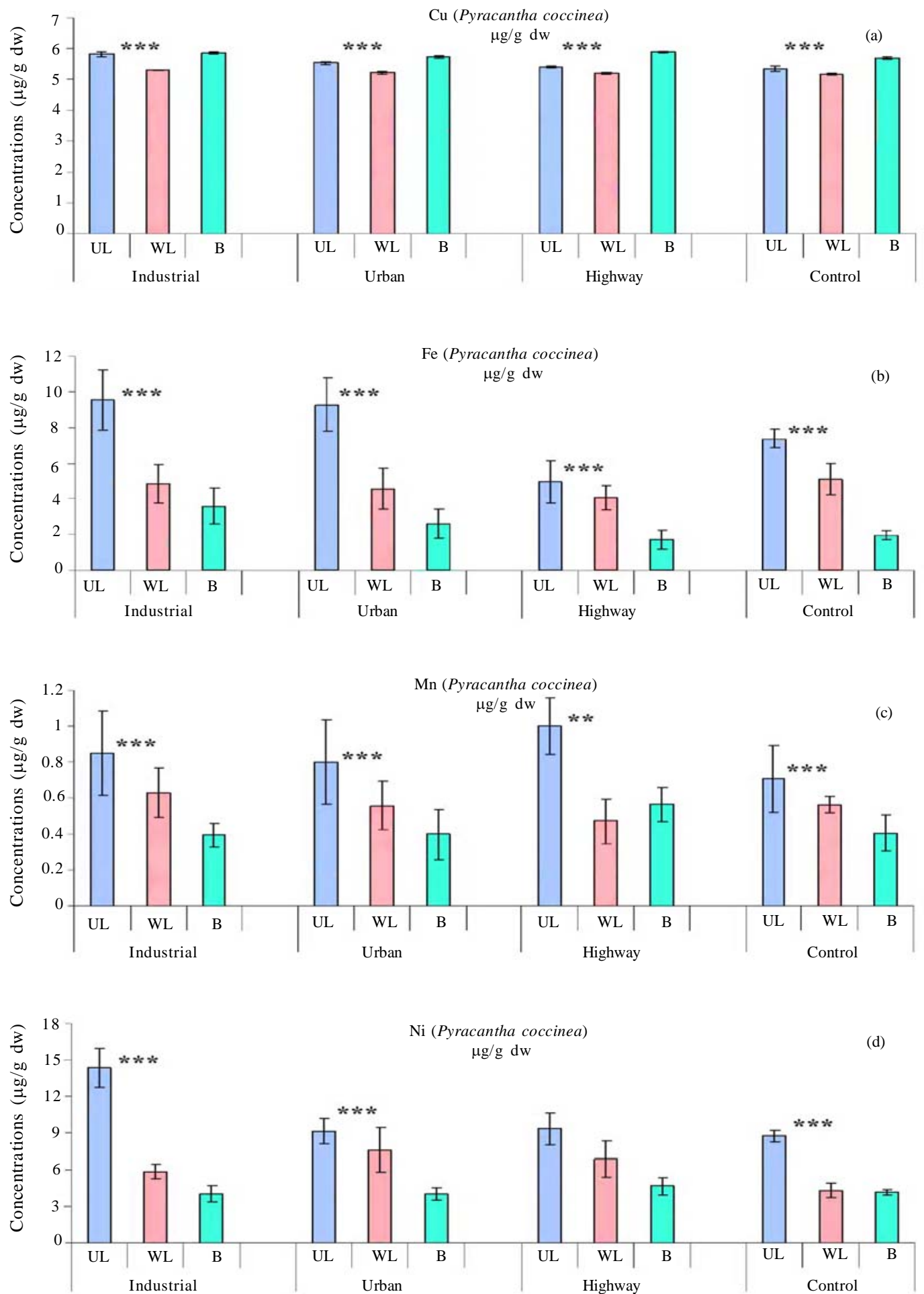

Fig. 2: Mean Cu (a), Fe (b) Mn (c) and Ni (d) concentrations ( $\mu \mathrm{g} / \mathrm{g} \mathrm{dw}$ ) in branches, washed and unwashed leaves as $\mu \mathrm{g} / \mathrm{g}$ dw together with S.E. bars. UL: Unwashed leaves, WL: Washed leaves and B: Branch, significances of differences between washed and unwashed plants, from $t$-test, are indicated above the columns $(* * P<0.01, * * *<0.001$ significant $)$ 
increased urbanization and industry. The distinguishing ability between airborne and soil-borne contamination was assessed by washing the leaves with deionized distilled water. Although washing procedures reduced $\mathrm{Fe}, \mathrm{Mn}$ and Ni levels of leaves on an average of $40 \%$, the reduction of $\mathrm{Cu}$ levels by washing was less in leaves (8-10\%). In some previous studies with other plants, the $\mathrm{Cu}$ reduction was also higher than current results (Aksoy and Ozturk, 1997; Aksoy et al., 2000; Celik et al., 2005). The results of Figs. 2 b, c and d indicate that there was substantial aerial deposition on the leaves for three of those elements (Fe $\mathrm{Mn}$ and $\mathrm{Ni}$ ), which was removed by the washing procedure. Furthermore, the highest Fe, $\mathrm{Mn}$ and Ni levels were found in unwashed leaves, the second highest levels were found in washed leaves and the lowest values were found in branches of $P$. coccinea. Nevertheless, the highest $\mathrm{Cu}$ values were found in branches and then unwashed and washed leaves, respectively and all the values were closer to each other. In this study, although the Fe values were higher in industrial and urban areas compared to highway and rural, totally, all the values were very low. This could be a result of the Mugla Province is being mostly a touristic city, and in general not affected by Fe pollution or $P$. coccinea is not a good biomonitor for Fe element. In addition, the results of a similar study, which was carried out in industrial areas of Mugla City with Pinus sp. and Olea europaea, were higher than ours $(214.5 \mu \mathrm{g} / \mathrm{g} \mathrm{dw}$ and $241.6 \mu \mathrm{g} / \mathrm{g}$ ) (Tuna et al., 2005). This situation could also support that $P$. coccinea is not a good biomonitor for Fe. In addition, Mn values of this study were under normal limits and when same comparison is made with the study of Tuna et al. (2005), the same conclusion is deduced as Fe. Ni values of this study were higher than normal limits and especially higher in industrial area and washing procedure reduced Ni values in leaves. This result shows that Mugla is under $\mathrm{Ni}$ pollution. In conclusion, this study supports the view that $P$. coccinea could be used as a biomonitor for $\mathrm{Cu}$ and $\mathrm{Ni}$ metals, especially with its branches and leaves. However, for Fe and Mn metals, it could not be used as a biomonitor or other supportive studies could be carried out in other cities especially in industrialized cities with $P$. coccinea.

\section{ACKNOWLEDGEMENTS}

Special thanks to undergraduate laboratory assistant Miss. Busecan Aksoydan for rearranging the Tables and Figs. and research assistant Mr. Ahmet Yilmaz for rechecking language of the document.

\section{REFERENCES}

Acar, L., (1998). Mugla ilinin sosyo-ekonomik yapisi. M.Sc. thesis, Anadolu University, Eskisehir, Turkey.

Akguc, N.; Ozyigit, I. I.; Yarci, C., (2008). Pyracantha coccinea Roem. (Rosaceae) as a biomonitor for $\mathrm{Cd}, \mathrm{Pb}$ and $\mathrm{Zn}$ in Mugla province (Turkey). Pak. J. Bot., 40 (4), 1767-1776 (10 pages).

Aksoy, A.; Ozturk, M. A., (1997). Nerium oleander as a biomonitor of lead and other heavy metal pollution in Mediterranean environments. Sci. Total Environ., 205 (23), 145-150 (6 pages).

Aksoy, A.; Hale, W. H. G.; Dixon, J. M., (1999). Capsella bursapastoris (L.) Medic. as a biomonitor of heavy metal pollution. Sci. Total Environ., 226 (2-3), 177-186 (10 pages).

Aksoy, A.; Sahin, U., (1999). Elaeagnus angustifolia L. as a biomonitor of heavy metal pollution. Turk. J. Bot., 23, 83-87 (5 pages).

Aksoy, A.; Sahin, U.; Duman, F., (2000). Robinia pseudoacacia L. as a possible biomonitor of heavy metal pollution in Kayseri. Turk. J. Botany., 24, 279-284 (6 pages).

Aksoy, A.; Demirezen, D.; Duman, F., (2005). Bioaccumulation, detection and analysis of heavy metal pollution in Sultan Marsh and its environment. Water Air Soil Pollut., 164 (1-4), 241255 (15 pages).

Aksoy, A., (2008). Chicory (Cichorium intybus L.): A possible biomonitor of metal pollution. Pak. J. Bot., 40 (2), 791-797 (7 pages).

Allaway, W. H., (1968). Agronomic controls over the environmental cycling of trace elements. Adv. Agron., 20, 235-274 (10 pages).

Augusto, S.; Catarino, F.; Branquinho, C., (2007). Interpreting the dioxin and furan profiles in the lichen Ramalina canariensis steiner for monitoring air pollution. Sci. Total Environ., 377 (1), 114-123 (10 pages).

Bean, W., (1981). Trees and shrubs hardy in Great Britain. Vol: 14 and Supplement, Murray Press, U.K.

Bowen, H. J. M., (1979). Environmental chemistry of the elements. Academic Press, London, U.K.

Calzoni, G. L.; Antognoni, F.; Pari, E.; Fonti, P.; Gnes, A.; Speranza, A., (2007). Active biomonitoring of heavy metal pollution using Rosa rugosa plants. Environ. Pollut., 149 (2), 239-245 (7 pages).

Celik, A.; Kartal, A.; Akdogan, A.; Kaska, Y., (2005). Determining the heavy metal pollution in Denizli (Turkey) by using Robinia pseudoacacia L. Environ. Int., 31 (1), 105-112 (8 pages).

Czarnowska, K.; Milewska, A., (2000). The content of heavy metals in an indicator plant (Taraxacum Officinale) in Warsaw. Pol. J. Environ. Stud., 9 (2), 125-128 (4 pages).

Davis, P. H., (1972). Flora of Turkey and the East Aegean Islands. Vol: IV, Edinburgh University Press, Scotland.

Elik, A.; Akcay, M., (2000). Sivas kentinde agir metal kirliliginin yerel ve zamansal degisimi. Tr. J. Eng. and Env. Sci., 24 , 1524 (10 pages).

Figueiredo, A. M. G.; Nogueira, C. A.; Saiki, M.; Milian, F. M.; Domingos, M., (2007). Assessment of atmospheric metallic pollution in the metropolitan region of Sao Paulo, Brazil, employing Tillandsia usneoides L. as biomonitor. Environ. Pollut., 145 (1), 279-292 (4 pages).

Huxley, A., (1992). The new RHS dictionary of gardening. MacMillan Press, ISBN 0-333-47494-5, London, U.K.

Kabata-Pendias, A.; Pendias, H., (2001). Trace elements in soils

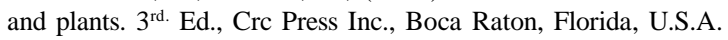


Kacar, B.; Katkat, V.; Ozturk, S., (2002). Bitki fizyolojisi. Uludag Univ. Press, No:198, Vipas. No:74, Livane Press, 563, Bursa, Turkey.

Kacar, B.; Inal, A., (2008). Bitki analizleri. Nobel Press, ISBN 978-605-395-036-3, Ýstanbul, Turkey.

Kovalchuk, I.; Kovalchuk, O.; Hohn, B., (2001). Biomonitoring the genotoxicity of environmental factors with transgenic plants. Trends. Plant. Sci., 6 (7), 306-310 (5 pages).

Levy, D. B.; Redente, E. F.; Uphoff, G. D., (1999). Evaluating the phytotoxicity of $\mathrm{Pb}-\mathrm{Zn}$ tailings to big bluestem (Andropogon gerardii Vitman) and switchgrass (Panicum virgatum L.). Soil Sci., 164 (6), 363-375 (9 pages).

Madejon, P.; Maranon, T.; Murillo, J. M., (2006). Biomonitoring of trace elements in the leaves and fruits of wild olive and holm oak trees. Sci. Total Environ., 355 (1-3), 187-203 (17 pages).

Mahvi, A. H., (2008). Application of agricultural fibers in pollution removal from aqueous solution. Int. J. Environ. Sci. Tech., 5 (2), 275-285 (11 pages).

Malakootian, M.; Nouri, J.; Hossaini, H., (2009). Removal of heavy metals from paint industries wastewater using Leca as an available adsorbent. Int. J. Environ. Sci. Tech., 6 (2), 183-190 (8 pages)

Mertens, J.; Vervaeke, P.; De Schrijver, A.; Luyssaert, S., (2004). Metal uptake by young trees from dredged brackish sediment: limitations and possibilities for phytoextraction and phytostabilisation. Sci. Total Environ., 326 (1-3), 209-215 (7 pages).

Mertens, J.; Luyssaert, S.; Verheyen, K., (2005). Use and abuse of trace metal concentrations in plant tissue for biomonitoring and phytoextraction. Environ. Pollut., 138 (1), 1-4 (4 pages).

Mugla Municipality, (2010). http://www.mugla-bld.gov.tr

Nameni, M.; Alavi Moghadam, M. R.; Arami, M., (2008). Adsorption of hexavalent chromium from aqueous solutions by wheat bran. Int. J. Environ. Sci. Tech., 5 (2), 161-168 (8 pages).

Nriagu, J. O., (1979). Global inventory of natural and anthropogenic emission of trace metals to the atmosphere. Nature, 279, 409-411 (3 pages).

Nylander, W., (1886). Les lichens du Jardin du Luxembourg. B. Soc. Bot. Fr., 13, 364-372 (9 pages).

Okafor, E. Ch., Opuene, K., (2007). Preliminary assessment of trace metals and polycyclic aromatic hydrocarbons in the sediments. Int. J. Environ. Sci. Tech., 4 (2), 233-240 (8 pages).

Prasad, N. M. V.; Freitas, H. M. O., (2003). Metal hyperaccumulation in plants - biodiversity prospecting for phytoremediation technology. Electron. J. Biotech., 6 (3), 285321 (37 pages).

Sakurai, T.; Kim, J.; Suzuki, N.; Matsuo, T.; Li, D.; Yao, Y. et al., (2000). Polychlorinated dibenzo- $p$-dioxins and dibenzofurans in sediment, soil, fish, shellfish and crab samples from Tokyo Bay area, Japan. Chemosphere, 40 (6), 627-640 (14 pages).

Taylor, D. J. C.; Page, D. C.; Geldenhuys, P., (1988). Iron and steel in South Africa. J. South Afr. Inst. Min. Metal., 88 (3), 73-95 (23 pages).

Tuikapp, (2010). The Official Web Site Turkish Republic Office of Prime Ministry Statistics Institution. http://tuikapp.tuik.gov.tr

Tuna, A. L.; Yagmur, B.; Hakerlerler, H.; Kilinc, R.; Yoka, I.; Burun, B., (2005). Mugla bölgesindeki termik santrallerden kaynaklanan kirlilik uzerine araptýrmalar. Mugla University BAP, Mugla. http://www.mu.edu.tr/departments/biyoloji/_private/ ozgecmisler/termik.pdf

Uhlig, C.; Junttila, O., (2001). Airborne heavy metal pollution and its effects on foliar elemental composition of Empetrum hermaphroditum and Vaccinium myrtillus in Sor-Varanger, Northern Norway. Environ. Pollut., 114 (3), 461-469 (9 pages).

Wittig, R., (1993). General aspects of biomonitoring heavy metals by plants. In: Markert, B. (Ed.), Plants as biomonitors indicators for heavy metals in the terrestrial environment. Weinheim: VCH Publisher, 3-28 (26 pages).

Wolterbeek, B., (2002). Biomonitoring of trace element air pollution: principles, possibilities and perspectives. Environ. Pollut., 120 (1), 11-21 (11 pages).

Yasar, U.; Ozyigit, I. I., (2009). Use of human hair as a potential biomonitor for zinc in the Pendik District Istanbul Turkey. Rom. Biotech. Lett., 14 (3), 4477-4484 (8 pages).

Yasar, U.; Ozyigit, I. I.; Serin, M., (2010). Judas tree (Cercis siliquastrum L. subsp. siliquastrum) as a possible biomonitor for $\mathrm{Cr}, \mathrm{Fe}$ and $\mathrm{Ni}$ in Istanbul (Turkey). Rom. Biotech. Lett., 15(1), 4983-4992 (10 pages).

Yilmaz, R.; Sakcali, S.; Yarci, C.; Aksoy, A.; Ozturk, M., (2006). Use of Aesculus hippocastanum L. as a biomonitor of heavy metal pollution. Pak. J. Bot., 38 (5), 1519-1527 (9 pages).

\begin{abstract}
AUTHOR (S) BIOSKETCHES
Akguc, N., M.Sc., Marmara University, Faculty of Science and Arts, Department of Biology, 34722, Goztepe, Istanbul, Turkey. Email: nihan1982@hotmail.com

Ozyigit, I. I., Ph.D., Marmara University, Faculty of Science and Arts, Department of Biology, 34722, Goztepe, Istanbul, Turkey. Email: ilkozyigit@marmara.edu.tr

Yasar, U., Ph.D., Assistant Professor, Bartin University, Faculty of Engineering, Environmental Engineering Department, 74100, Bartin, Turkey. Email: uyasar@bartin.edu.tr

Leblebici, Z., Ph.D., Erciyes University, Faculty of Science and Arts, Department of Biology, 38039, Kayseri, Turkey. Email: zleblebici@erciyes.edu.tr

Yarci, C., Ph.D., Full Professor, Marmara University, Faculty of Science and Arts, Department of Biology, 34722, Goztepe, Istanbul, Turkey. Email: celalyarci@marmara.edu.tr
\end{abstract}

Akguc, N.; Ozyigit, I. I.; Yasar, U.; Leblebici, Z.; Yarci, C., (2010). Use of Pyracantha coccinea Roem. as a possible biomonitor for the selected heavy metals. Int. J. Environ. Sci. Tech., 7 (3), 427-434. 